\title{
Some indigenous uses of plants in pre-Columbian Puerto Rico ${ }^{1}$
}

\author{
Reniel Rodríguez Ramos ${ }^{2}$, Jaime Pagán Jiménez ${ }^{3}$, Jorge Santiago-Blay ${ }^{4}$, Joseph B. Lambert ${ }^{5}$, \\ and Patrick R. Craig ${ }^{6}$
}

\begin{abstract}
Pre-Columbian indigenous inhabitants settled Puerto Rico thousands of years before Columbus. Evidence supports the statements that, as a group, these peoples were competent farmers, and used plants ceremonially and ornamentally.
\end{abstract}

Key Words: pre-Columbian inhabitants, Puerto Rico, ethnobotany

Let us transport ourselves to pre-Columbian times and imagine how the first inhabitants of Puerto Rico lived thousands of years before the arrival of the Spaniards. For many of us, the images of indigenous people hunting, fishing and collecting wild fruits are the first that come to mind. Nevertheless, recent studies have shown that the pre-Columbian inhabitants of Boriquén, as the natives called Puerto Rico, did not depend exclusively on the kindnesses that the nature offered them. The primeval inhabitants of the island were also farmers had millenary phyto-cultural traditions, which allowed them to develop complex social systems. In other words, already from the beginnings of the occupation of the island, some agricultural practices had been introduced into Puerto Rico. These technological developments not only required the introduction of plants and cultivation techniques but also the production of an artifactual repertoire for their harvesting and processing as well as superstructural traditions and methodologies attached to those practices.

Diet. The available data indicate that Puerto Rican agriculture began at least 4.500 years ago (Pagán Jiménez et al. 2005; Rodríguez Ramos 2010). Microscopic analyses of starch granules preserved for thousands of years in the ground facets of stone tools that have been found in pre-Arawak contexts of Puerto Rico (Pagán Jiménez et al 2005; Pagán Jiménez 2009, 2011), indicating

\footnotetext{
${ }^{1}$ Submitted and accepted on February 28, 2013. This paper was accepted for publication in $E l$ Pedernal, the bulletin of the Geological Society of Puerto Rico, in the summer of 2012. Unfortunately, due to insufficient submissions, this paper could not be published. Editor, Dr. David Cuevas (University of Puerto Rico, Mayagüez Campus) allowed the authors to withdraw the paper.

2 University of Puerto Rico, P. O. Box 2500Utuado 00641-2500, Puerto Rico. E-mail: renielrodriguez@gmail.com

3 Faculty of Archaeology, University of Leiden, Reuvensplaats 3, 2311 BE Leiden, The Netherlands. E-mail: jpaganpr@yahoo.com

${ }^{4}$ Departament of Paleobiology, National Museum of Natural History, Washington, District of Columbia 20560 USA. E-mail: blayj@ si.edu

5 Department of Chemistry, Trinity University, San Antonio, Texas 78212-7200 USA and Northwestern University, Evanston, Illinois 60208 USA. E-mail: jlambert@ northwestern.edu

${ }^{6} 19380$ Pine Glade, Guerneville, California 95446 USA. E-mail: amberid@ comcast.com
}

DOI: 10.9784/LEB1(1)Rodriguez.09 
that the first pre-Columbian inhabitants of the island were already manipulating domestic and wild plants, some of which they imported from neighboring areas in the continental mainland. The cultivated botanical repertoire included corn (Zea mays L., Poaceae), yam or sweet potato (Ipomoea batatas (L.) Lam., Convolvulaceae), manioc (Manihot esculenta Crantz, Euphorbiaceae), and beans (Phaseolus vulgaris L., Fabaceae, and other species of legumes). Also, these pre-Arawak groups introduced less well-known plants, like yuquilla or arrowroot (Maranta arundinacea L., Marantaceae), gruya (Canna sp., Cannaceae), and arrowhead (Sagittaria latifolia, Alismataceae). In tandem with these introduced plants, those ancient societies utilized native species of cycads, particularly Zamia (Zamiaceae), better known as marunguey in Puerto Rico or guáyiga, in Hispaniola. This shows that the first inhabitants of Puerto Rico could eradicate the toxins contained in cycads and other plants in order to transform them into edible products. To confection foods from these plants, an artifact assemblage mainly composed of edge-ground cobbles, milling stones and irregular manos were employed (Figure 1). These allowed transforming the useful organs into masses or pastes that were converted into meals through different recipes (e.g. tamales, pastel, guanimes, sorullos, creams, bread Rodríguez Ramos 2005).

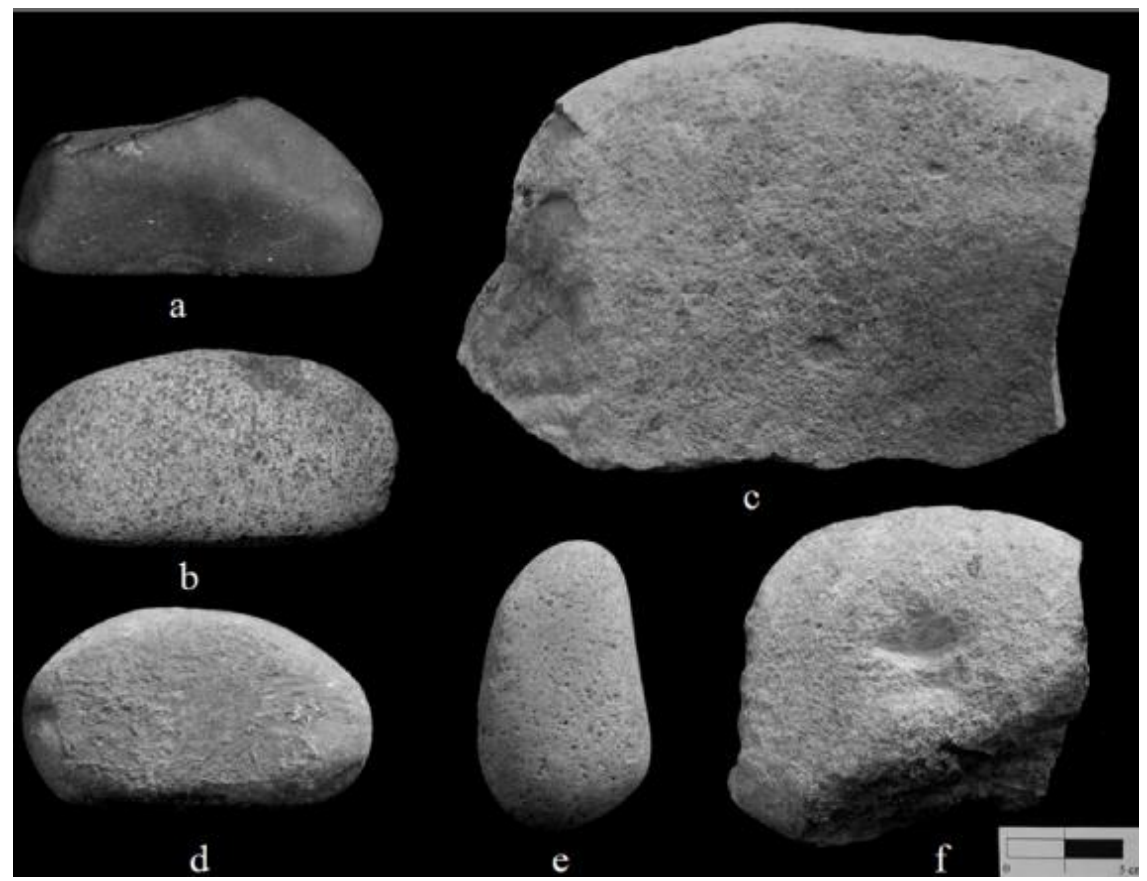

Figure 1. Edge ground cobbles (a, b, d), millingstone (c), irregular mano, and nutting stone (f) from Maruca, Puerto Ferro and Paso del Indio, Puerto Rico. 
Ceremonial. Archaeological studies have shown the great ritual complexityof all the native groups that inhabited Puerto Rico before Columbus. Paleoethnobotanical investigations conducted by Pagán Jiménez and Carlson (2012, submitted) sheds additional light on the information supplied by $15^{\text {th }}$ and $16^{\text {th }}$ century Spanish chroniclers concerning the ritual of the cohoba, Adenanthera peregrina (L.) Speg. (Fabaceae). Although the chroniclers described vividly the magic-religious uses of the cohoba, it is only recently when seeds of A. peregrina, not Nicotiana tabaccum L. (Solanaceae) as commonly assumed, have been formally identified as the source of hallucinogens through the study of starch remains of this plant stored in a ground coral artifact fragment. Cohoba seeds were ground and mixed with other materials, such as seashells or shattered bones, allowing its users to reach modified states of conscience and, as a consequence, new spheres of esoteric knowledge. Through the cohoba ritual, natives of the Antilles and South communicated with their deities, thus endowing A. peregrina with a role as visionary plant (Towers and Repke 2006).

Indigenous societies of Puerto Rico also made use of plant exudates or the usually organic materials that numerous plants, predominantly trees ooze (Lambert et al. 1999, 2005, 2007a, 2007b, 2007c, 2009, 2010, 2012, and submitted). These plant exudates were employed to manufacture personal adornments and other paraphernalia used in collective activities, as notedin the Spanish chroniclers. A prime example is a ball game called batú played in courts such as the Caguana Indigenous Ceremonial Park, the most notable multi-court site of the Caribbean, located in Utuado, Puerto Rico. Although no balls used by natives in Puerto Rico have been archaeologically reported, analyses of the balls used in Central American batús show that some constituents of tree Castilla elastica Sessé (Moraceae) were utilized in their production (Hosler et al. 1999). In a recent trip to Puerto Rico, one of us (JASB) found large trees of $C$. elastica near Highway 10, between Arecibo and Utuado. Some of the trees had abundant quantities of this elastic exudate.

Ornamentation. Besides the use of plants as food items and in ceremonial rituals, natives employed botanical resources as adhesives as well as in the manufacture of corporal decorations, sculptures, vessels, and other objects. Natives of the island represented their deities through figures, known as cemies (Figures 2,3) some of which were formed from local stones including marble, diorite, and calcie-rudite, the latter imported from Saint Martin. Likewise, they used various species of trees to create impressive religious representations. Such figures reflect the prodigious ability of the Puerto Rican and other Antillean pre-Columbian inhabitants to carve hard woods such as lignum vitae (Guaiacum officinale L., Zygophyllaceae) (Ostapkowicz et al. 2012). Some cemies have cavities in which inlays were placed that represented eyes, teeth or tokens (screens) concocted with clams or sheets of gold (Figure 4). Apparently, the natives utilized plant exudates in those cavities to set the decorative 
elements. In our examination of cemíes, we have found remains of what seem to be exudates in some cavities but never in sufficient quantities to allow chemical analyses and subsequent identification of their botanical provenance.
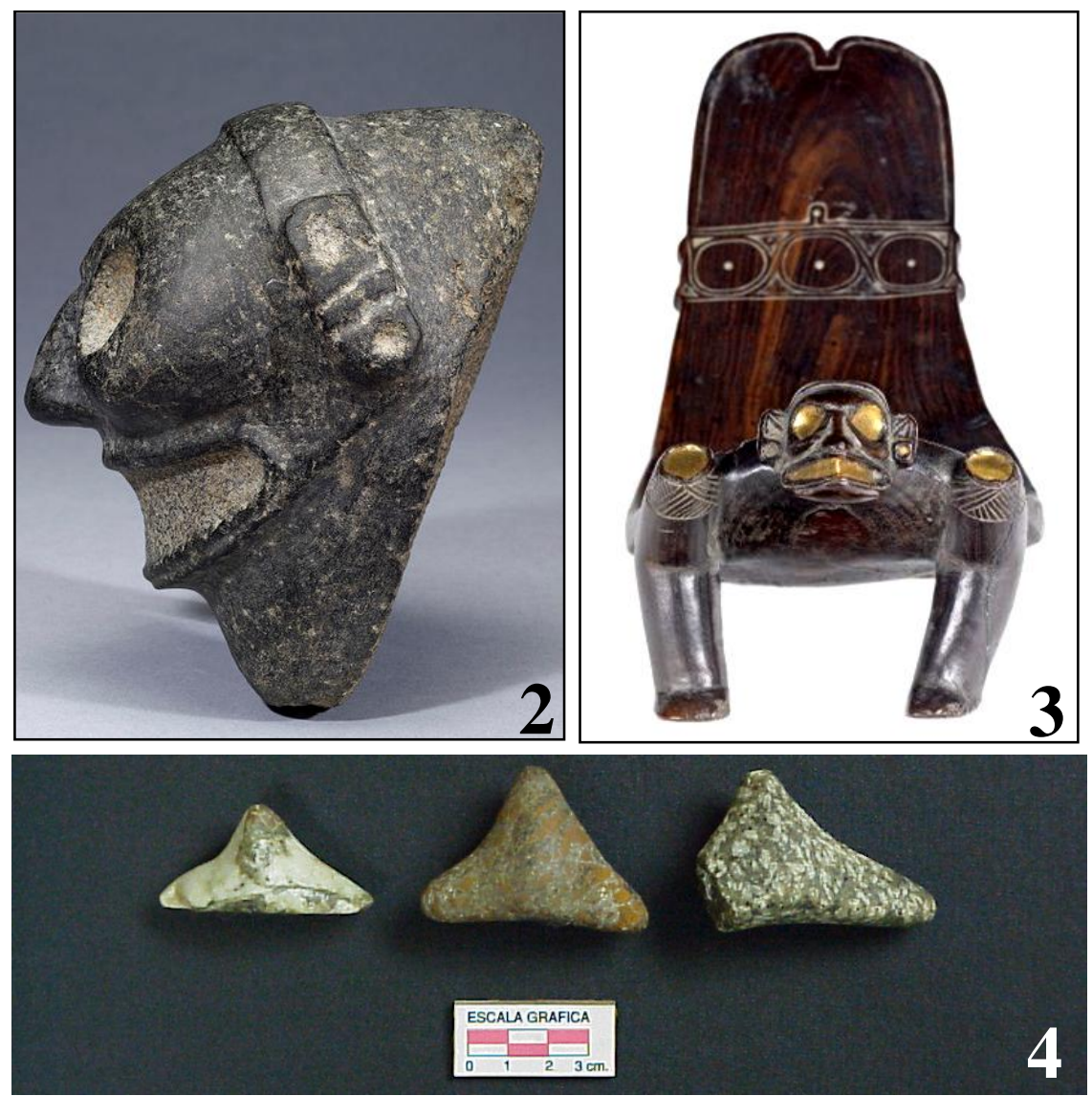

Figures 2-4. 2-3. Stone "cemíes". Figure 2 taken from http://en.wikipedia.org/wiki/File:Taino__Zemi__-Walters_20056___Left_Side.jpg . 3. Stone three-pointers (i.e. cemíes), Paso del Indio, Vega Baja, Puerto Rico. Left, marble; center, limonite; right, calcie-rudite. Image taken by author RRR. 4. Wooden "dujo" with golden encrustations in an anthropomorphic figure. Am1949,22.118,AN242124 Image from http://www.britishmuseum.org/join_in/using_digital_images/using_digital_images.aspx?asset_id=24 2124\&amp;objectId=651811\&amp;partId=1

Amber is fossilized resin (Lambert et al. 2008; Santiago-Blay and Lambert 2007). Some plants produce copious quantities of resin (Figure 6,7) and some resins form amber. For millennia, humans have used amber as ornament (Figures 8-10) or in ceremonial and civic ceremonies. Although amber is 
abundant in the Dominican Republic, in Puerto Rico and other Antilles little native amber has been found (Iturralde-Vinent 2001 and references therein). In Punta Candelero, Humacao (Puerto Rico), in a context associated with the Huecoid culture, a tubular resinous bead preform was recovered recently and it is currently been studied by some of us in order to chemically characterize it in an attempt to determine its provenance. Amber has been reported at the bottom of the Lake Guatavita (Colombia), an area famous for the histories of El Dorado (Anderson and Bray 2006). Copal or partially fossilized resin, is well known from Colombia, in contrast to Puerto Rico. Also, Mexican and Central American natives still use modern exudates as incense.
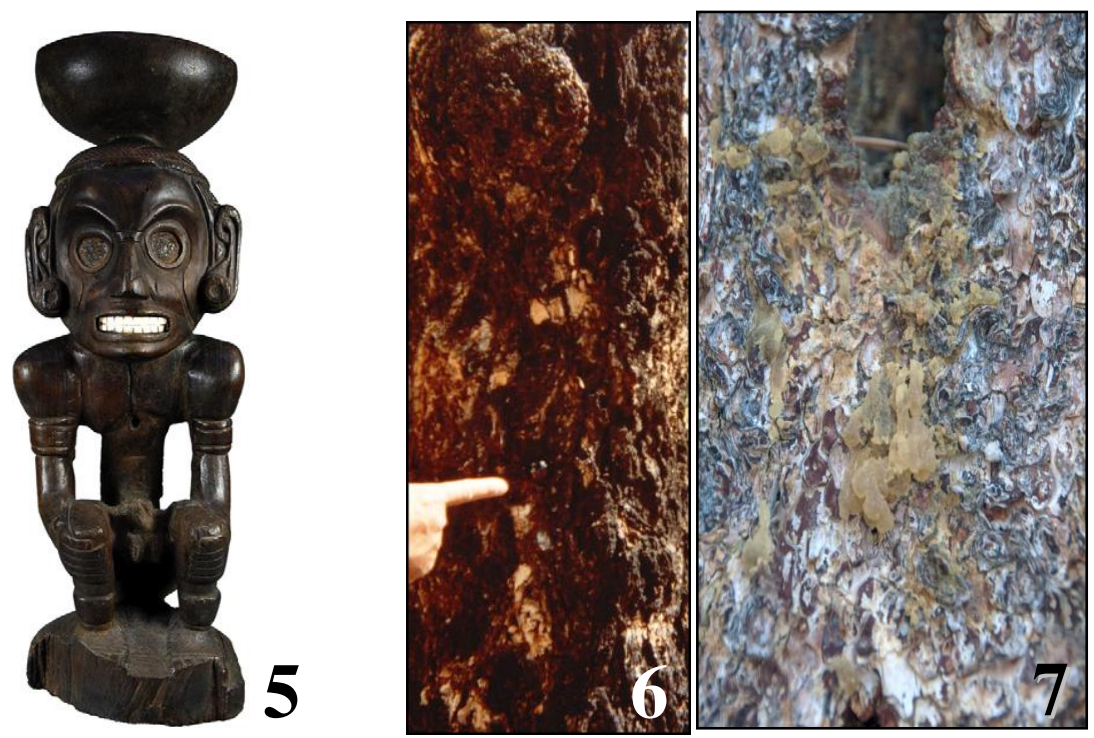

Figures 5-7. 5. Wooden idol from Jamaica (Jamaica) deposited at the British Museum. Photo from Oliver et al. 2008, courtesy of Dr. José Oliver. 6-7. Resin produced by 6. Bucida buceras L. (Combretaceae), or úcar, and by 7. an unidentified plant (photograph by author PC). 

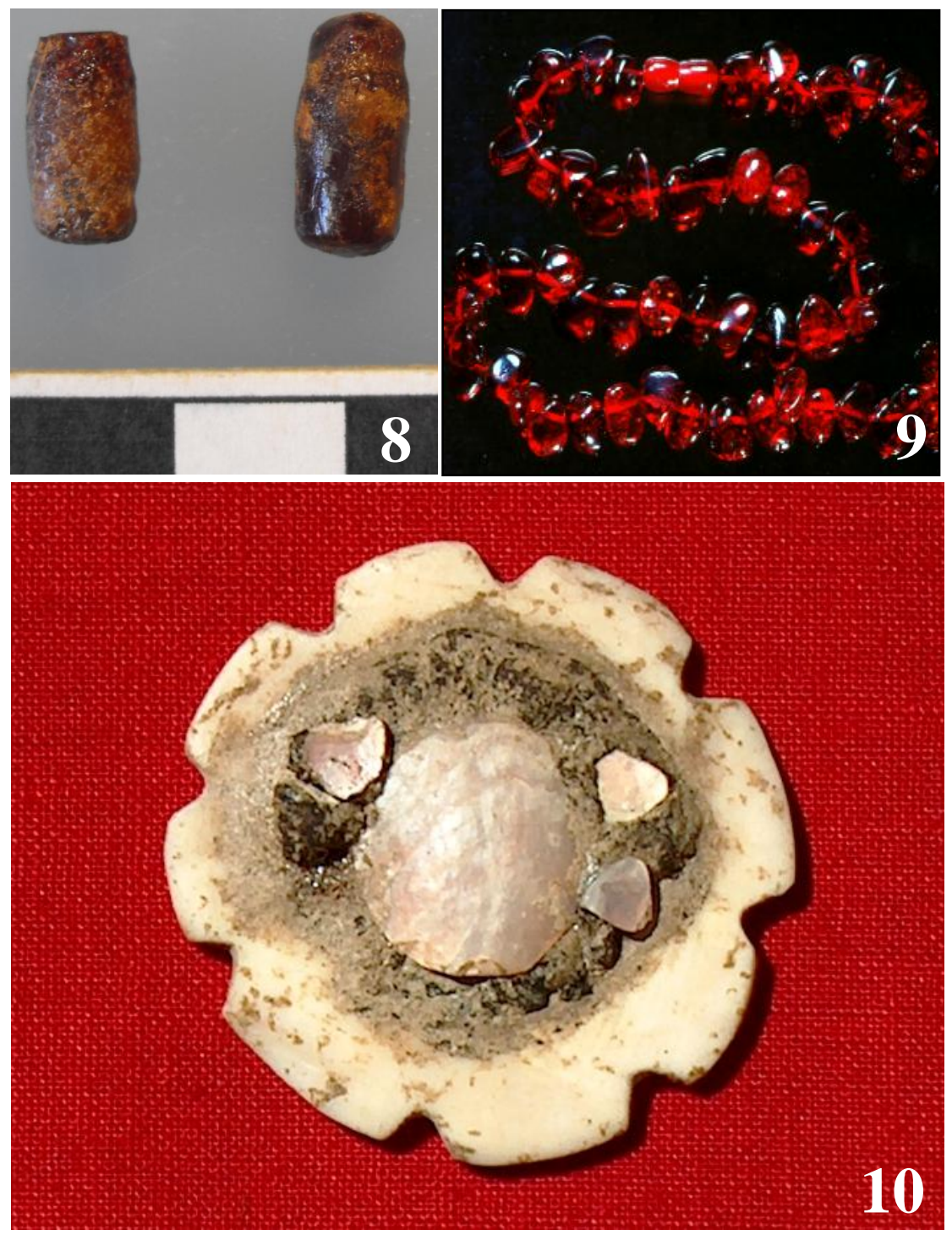

Figures 8-10. Ornamental uses of resins. 8. Possible proform ear ornament found in Cuba. Photograph courtesy of Roberto Valcárcel Rojas. A similar artifact has been found in eastern Puerto Rico. The deposit in eastern Puerto Rico has been C-14 dated to about 350-450 Common Era suggesting that its arrival in Puerto Rico vastly preceded that of the Europeans. Preliminary analyses suggest that it may have come from the Isthmian region in Meso- and South America. 9. Jewelry artifacts made out of of Chiaps (Mexico) amber. Photograph by author PC. 10. Shell denticulate adornment with mother of peral inlay, Punta Candelero, Humacao, Puerto Rico (courtesy of Miguel Rodríguez López). 
As has been evident throughout this work, the pre-Columbian peoples that settled Puerto Rico thousands of years before Columbus engaged in a complex set of phyto-cultural interactions. These indigenous societies were not only competent farmers since their earliest occupation of the island, but also developed a repertoire of botanical traditions that engaged them ritually with their floral landscape. Fortunately, new developments in archaeobotanical analysis have allowed us to get a better understanding of such practices and traditions, showing the complex ways in which humans and plants articulated through time in the island. The study of this evidence, coupled with the documentation of the indigenous practices that are still being performed in the island today, will allow us to get a better panorama of the phyto-cultural traditions that were practiced by the ancient societies of Puerto Rico and the rest of the Caribbean and will hopefully provide us with ways in which to interact more harmoniously with our botanical resources in the future.

\section{Literature Cited}

Anderson, K. B. and W. Bray. 2006. The amber of El Dorado. Class 1B archeological amivers associated with Laguna Guatavita. Archaeometry 48(4):633-640. http://dx.doi.org/10.1111/j.1475-4754.2006.00277.x

Hosler, D., S. L. Burkett and M. J. Tarkanian, 1999. Prehistoric Polymers: Rubber processing in ancient Mesoamerica. Science 284(5422):1988-1991. http://dx.doi.org/10.1126/science.284.5422.1988

Iturralde-Vinent, M. A. 2001. Geology of the amber-bearing deposits of the Greater Antilles. Caribbean Journal of Science 37(3-4):141-166.

Lambert, J. B., E. W. Donnelly, E. A. Heckenbach, C. L. Johnson, M. A. Kozminski, Y. Wu, and J. A. Santiago-Blay. Natural exudates of the rosids. (Submitted)

Lambert, J. B., E. R. Heckenbach A. E. Hurtley, Y. Wu, and J. A. Santiago-Blay. 2009. Nuclear magnetic resonance spectroscopic characterization of legume exudates. Journal of Natural Products 72:1028-1035. http://dx.doi.org/10.1021/np900188j

Lambert, J. B, E. A. Heckenbach, Y. Wu, and J. A. Santiago-Blay. 2010. Characterization of plant exudates by principal component and cluster analysis with nuclear magnetic resonance $\begin{array}{llll}\text { variables. Journal of Natural Products 73(10):1643-1648. } & \end{array}$ http://dx.doi.org/10.1021/np100318n

Lambert, J. B., M. A. Kozminski, C. A. Fahlstrom, and J. A. Santiago-Blay. 2007a. Proton nuclear magnetic resonance characterization of resins from the family Pinaceae. Journal of Natural Products 70(2):188-195. http://dx.doi.org/10.1021/np060486i

Lambert, J. B., M. A. Kozminski, and J. A. Santiago-Blay. 2007b. Distinctions among conifer exudates by proton magnetic resonance spectroscopy. Journal of Natural Products 70(8):12831294. http://dx.doi.org/10.1021/np0701982

Lambert, J. B., J. A. Santiago-Blay, and K. B. Anderson. 2008. Chemical signatures of fossilized resins and recent plant exudates. Mini Review. Angewandte Chemie (International Edition) 47:9608-9616. Also published in German, with the following bibliographic information: Chemischer Fingerabdruck von fossilen Harzen und rezenten Pflanzenexsudaten. Angewandte Chemie 120:9750 - 9760.

Lambert, J. B., C. E. Shawl, G. O. Poinar, Jr., and J. A. Santiago-Blay. 1999. Classification of modern resins by solid nuclear magnetic resonance spectroscopy. Bioorganic Chemistry 27:409-433. http://dx.doi.org/10.1006/bioo.1999.1147

Lambert, J. B., C. Y.-H. Tsai, M. C. Shah, A. E. Hurtley, and J. A. Santiago-Blay. 2012. Distinguishing amber classes by proton magnetic resonance spectroscopy. Archaeometry 54(2):332-348. http://dx.doi.org/10.1111/j.1475-4754.2011.00625.x 
Lambert, J. B., Y. Wu, and M. A. Kozminski, and J. A. Santiago-Blay. 2007c. Characterization of Eucalyptus and chemically related exudates by nuclear magnetic resonance spectroscopy. Australian Journal of Chemistry - an International Journal for Chemical Science 60:862-870. http://dx.doi.org/10.1071/CH07163

Lambert, J. B. Y. Wu, and J. A. Santiago-Blay. 2005. Taxonomic and chemical relationships revealed by nuclear magnetic resonance spectra of plant exudates. Journal of Natural Products 68(5):635-648. http://dx.doi.org/10.1021/np050005f

Oliver,J. R. 2008. El universo material y espiritual de los taínos. pp. 136-221. In, Oliver,J R., McEwanC., Casas Gilberga, A. (Editors). El Caribe precolombino: Fray Ramón Pané y el universo taíno. Barcelona: Ajuntament de Barcelona-Instut de Cultura, Museu Barbier Mueller. Ministerio de Cultura-Madrid and CaixaGalicia. 285 pp.

Ostapkowicz, J., C. B. Ramsey, F. Brock, T. Higham, A. C. Wiedenhoeft, E. Ribechini, J., J. Lucejko, and S. Wilson. 2012. Chronologies in wood and resin: AMS 14C dating of preHispanic Caribbean wood sculpture. Journal of Archaeological Science 39(7): 2238-2251. http://www.sciencedirect.com/science/article/pii/S0305440312000477 http://dx.doi.org/10.1016/j.jas.2012.01.035

Pagán Jiménez, J. R. 2009. Nuevas perspectivas sobre las culturas botánicas precolombinas de Puerto Rico: implicaciones del estudio de almidones en herramientas líticas, cerámicas y de concha. Cuba Arqueológica II(2): 7-23.

Pagán Jiménez, J. R. 2011. Early phytocultural processes in the precolonial Antilles: A panCaribbean survey for an ongoing starch grain research. pp. 87-116. In, Communities in Contact. Essays in Archaeology, Ethnohistory, and Ethnography of the Amerindian CircumCaribbean. C. L. Hoffman and A. Duijvenbode (Editores). Sidestone Press. Leiden, Holland. $510 \mathrm{pp}$.

Pagán Jiménez, J. R., M. Rodríguez, L. Chanlatte, and Y. Narganes. 2005. La temprana introducción y uso de algunas plantas domésticas, silvestres y cultivos en las Antillas precolombinas. Una primera revaloración desde la perspectiva del "arcaico" de Vieques y Puerto Rico. Diálogo Antropológico 3(10):7-33.

Pagán Jiménez, J. R. and L. Carlson. 2012. Recent archeobotanical findings of the hallucinogenic snuff Cohoba (Anadenanthera peregrina (L.) Speg.) in precolonial Puerto Rico. Latin American Antiquity (Submitted).

Ramos, R. 2005. The function of the edge-ground cobble put to the test: an initial assessment. Journal of Caribbean Archaeology 6:1-22.

Rodríguez Ramos, R. 2010. Rethinking Puerto Rican precolonial history. The University of Alabama Press. Tuscaloosa, Alabama, USA. 267 pp.

Santiago-Blay, J. A. and J. B. Lambert. 2007. Amber's botanical origins uncovered. American Scientist 95:150-157.

Torres, C. M. and D. B. Repke. 2006. Anadenanthera: Visionary plant of ancient South America. The Haworth Herbal Press. New York, NY, USA. 256 pp. 